\title{
Retention of English language tension in multilingual communities of Nepal: A review of teachers' narratives
}

Karna Rana

\begin{abstract}
:
This article discusses the voices of teachers about shifting from Nepali to English medium in community schools in Nepal and suggests ways to solve some of the problems of the English language in schools of multilingual communities. The article is based on previously published teachers' narratives in several issues of ELTChoutari webmagazine in the past ten years. The teachers' narratives, which are discussed in this article, focused on English language teaching pedagogies in Nepali government schools. Thearticle analyses the problems, which several teachers raised in their narrative articles, and offers some suggestions to overcome them. The article begins with a discussion about the multilingual context of Nepal, language policy and the English language in schools. Moreover, the article discusses community schools' interest in the English language, teachers' perceptions of English as a medium of instruction and schools' expectations of improving educational quality.
\end{abstract}

Keywords: English language, multilingual community, language policy, school education

\section{Introduction}

It is important to start with context, an environment where particularly the disposition of several indigenous languages is nuanced by various traditional performance and expression of diverse community people. Nepal, a small country, which occupies an area of 147,181 square kilometres, has a broad range of sociocultural, linguistic, religious and topographic diversities. Out of the total land, the Himalayan region occupies 23\%, the Hilly $60 \%$ and the Terai $17 \%$. The regions as reported in the 2011 Census constitute $50.27 \%, 43 \%$ and $6.73 \%$ of the total population respectively (Central Bureau of Statistics, 2011; published 2012 November). The 2011 Census report stated that about $80 \%$ of the total population live in rural areas whereas only $20 \%$ reside in cities. The report of the diversity of languages and ethnic communities may seem very strange to rest of the world who might see Nepal as a small homogenous country. The census reported 125 ethnic communities and 123 languages spoken as a mother tongue. Nepali, which is the national language and is spoken as the mother tongue by $44.6 \%$ of the total population, also has various dialects in different regions. The majority of these languages, which do not have own script 
and are transferred from one generation to another verbally, are gradually losing speakers and dying slowly. Although the reestablishment of democracy in 1991 provided rights to language in the country, there is no clear policy on bilingual education. Weinberg (2013) reports that the language policy in Nepal is chaotic and complicated to follow. In recent years, the debate on language policy and bilingual education has drawn the attention of government and members of the public. However, the government of Nepal does not clearly define the right to education in mother tongue in the recently passed Nepal's Constitution, 2015 and does not clearly define the space of the English language in education. Many state schools' shifting from Nepali to English medium in the recent years has been a concern in Nepal's education.

Some studies (Alexander, 2009; Phillipson, 1996; Shannon, 1995) reported English language hegemony in the classroom where bilingual students study specifically in African school classrooms. However, the dominant role of a language is countryspecific, much more connected with colonialism in many countries in the world. Alexander (2009) argues that in the colonial period, English language policy suppressedthenative languages of South African countries and many of the local languages gradually got the minority status. Even in the United States, hundreds of languages are looking for a shared space in the classroom, but the policy of English language restrains the entry of bilingual education. For example, Macedo, Dendrinos, and Gounari (2005)argue that, although research in language acquisition acknowledged the advantages of bilingual education, a slogan like English for all children in the United States dominates the empirical evidence supporting bilingual education and educators manipulate research findings to eliminate bilingual education. Although the context in Nepal is different than that of African, American, European and many Asian countries, the hegemony of one language over several languages is similar to their contexts. In the absence ofbilingual education policy in Nepal, the Nepali language among 123 native languages of Nepal gets overarching space in education and the English, in fragile language policy, is seemingly overtaking the race with the Nepali particularly in private schools.

Many of the native languages in Nepal lack orthographic systems, which is perhaps one of the difficulties to raise, preserve and bring them into education (Phyak, 2011), but it is not enough to justify why bilingual education does not get space in the classroom. Although several organisations, particularly ethnic community organisations, have been raising voice about language and primary education in mother tongue for several decades, it is still, in a way, awaiting clear language policy and other way seeking help develop language systems. Phyak (2011) argues that school education and the choice of medium of instruction has become a more pressing issue since Education Act, 2002 empowered School Management Committee (SMC) of state schools with the decentralised school management system. He states that many government schools are gradually shifting from Nepali to English medium to attract a maximum number of students. The decentralised school management system allowed the SMC to mobilise local communities, generate resources and sustain education programmes (Rana, 2018). However, its results are observed more in shifting state schools from Nepali to English medium particularly in cities and recruitment of teachers in the schools. People's attraction towards private schools, which are English medium, also indicates that the English language is gradually expanding its space in education in Nepal. However, the fragile language policy of the government of Nepal seems to be a loophole 
for the growth of the English language. There are tensions such as identity crisis, job opportunities, quality of education, fragile policy on language and medium of instruction in the classroom teaching, which are discussed in this article below.

\section{The fear of losing native identity}

Many researchers including McCrone and Bechhofer (2008), Luhtanen and Crocker (1992) and Jenkins (2004) explained social identity, which is different from individual identity that includes attributes of personal competence, talent and ability, as an association of a person with a group of people based on race, gender and occupation. However, it is not definitive in meaning as it is the shared understanding of commonness. The identity of someone depends on various situations such as national identity in an international event and regional identity in the national conference. Moreover, the claim of identity relies on the interpretation of identity markers such as birthplace, ancestry, accent, appearance and dress, language, and many others as indicators of national identity (McCrone \& Bechhofer, 2008). The narratives of several Nepali teachers, for instance, the following excerpt from the narrative of Prem Phyak who is an English teacher at a Nepali university, reflect tension about gradually losing native language as a national identity by giving emphasis on the English language in education:

What steps should Nepal take to maintain its linguistic and cultural heritage from the potential "killer" characteristics of English? This question has a great implication not only for English language teachers but also for the whole notion. This indicates that being ELT practitioners we should also look after a unique linguistic and cultural diversity we have. This is our responsibility to address the values, skills, attitudes, and cultures of people while teaching English (Pyhak, 2011).

Phyak'snarrative reflects a silence of citizens of Nepal that the emphasis on the English language in education may diminish social and cultural characteristics, indicators of national identity. Moreover, his account suggests that English teachers in Nepal's multilingual communities should bear the social as well as national responsibility when teaching the English in the classroom. Many of 123 languages are endangered in Nepal and Phyak's concern indirectly advises the Government of Nepal and its citizens to be aware of the possible loss of endangered languages and to be responsible when prioritising the English in education. Perhaps the language endangerment is similar to, as Krauss (1992)says, endangerment of their ethnicity in a social ecosystem. Uttam Gaulee, who has been a teacher in Nepal for many years and is currently a faculty in an American university argues that among many reasons, allowing international development organisations, for example, Nordic NGOs to invest in Nepal's education has promoted the English language in schools and influenced local languages:

Why do parents, societies, and educational systems favour dominant languages against their own local languages? One of the most important reasons for this is the invisible hands of money. When countries or educational establishments receive cash from someone, they have to meet the expectations of the donors (Gaulee, 2012).

Gaulee, in his narrative, argues that the responsible government authorities and educational organisations are 
systematically imposing the English language over the majority of people, who live on little crops without a reliable source of income and follow what education systems and organisations bring, and intending to replace the diversity of languages in Nepal. However, Sajan Kumar Karn, an English teacher in Nepal, stresses that the hierarchical status legally agreed of certain languages in the country becomes a monster of many other local languages:

The spread of the English is not the direct cause of language endangerment. The English, in fact, has its effects on national (major languages) not on regional and minority languages. In many countries, it is the national language, such as Nepali that threatens local languages, not English (Karn, 2009).

Karn argues that the major threat for several indigenous languages in Nepal is from the Nepali language, only the official language in the country. However, on one hand, he, as his narrative reflects, does not seem to be aware of research findings in other developing countries. For example, the findings of Mustapha (2014) in Nigeria suggest that the rapid growth, acceptance and use of the English is not only threatening the local languages but also shifting them from the communities which may lead to a loss. Lane (2017 May 10) reported that the widespread of the English hegemony is not affecting only local languages in many countries but also showing the danger of monoculture although we want differences and varieties and our civilisation is a rich garden of colourful flowers. His metaphor "garden" indicates social, cultural and linguistic diversity as our identity.

On the other hand, Karn's account aligns with the argument of Giri (2009) who raises a valid issue in Nepal's context where the government policy instigates only the
Nepali language considering it as an instrument to unify all the communities and the English as a compulsory language for all to learn in schools, regardless of recently promulgated Nepal's Constitution, 2015(Constitutional Assembly Secretariate, 2015) vaguely states that the state governments may decide their official language which is still impending. However, the narrative of Mahendra Kathet, a retired teacher who is working as a teacher trainer in Mt Everest region in Nepal indicates that teachers in government schools emphasise the English language to teach lessons for certain reasons:

English language, which is the most widely spoken language, makes communication possible in any part of the world. The English language transformed the gigantic world into a small community. It is an enormous medium of world knowledge and affairs. Majority of the web-pages are written in English. Knowledge of English skills, therefore, allows us to enter the world's ruling intellectual resources (2015).

Kathet's narrative reflects the innocence of Nepali citizens who have only read but never experienced the suppression of colonial governance. His account extends the voice of current generation youths who are growing with the rapid development of modern digital technology and aiming to explore opportunities across the world. The English language being an international language perhaps allows people to access a wide range of opportunities in most of the parts of the world. However, several researchers (Guo \& Beckett, 2007; Krauss, 1992; Mustapha, 2014; Tupas, 2001) reported that the English language in colonial and post-colonial period endangered several local languages in many, particularly colonised countries. Kathet focuses on making the English as a 
medium of instruction in Nepali schools without considering the social, cultural and linguistic diversity in Nepal and the hidden interest of imposing the English in Nepal's education.

\section{Prospective opportunities in the international market}

Several teachers' narratives indicate that the English language knowledge and skills open doors of a number of opportunities for the currently growing generation of youths across the world. The teachers through their writing emphasise the teaching of English from the very beginning of formal school, which has already been started in Nepal and teaching other subjects in English. The rapidly growing number of private schools, which claim they are English medium, and the expanding volume of students enrolled into English language department in Nepali universities also indicate the attraction of people particularly youths towards English language learning. In the recent years, a number of government schools even in rural areas have shifted to English medium from Nepali medium, however no record of how many schools adopted English as a medium of instruction is found, and the trend is widely increasing. For instance, a quarter of sixty schools in Lukla, one of the mountainous districts where Mt Everest lies, adopted English as a medium of instruction in the year 2013 with the support of REED, an NGO that has worked for several international nongovernmental organisations (INGOs) such as Himalayan Trust New Zealand, Australian Himalayan Foundation, American Himalayan Foundation, and many others. For the reference, I, one of the volunteers to train many teachers from different schools in one of the schools in Lukla in 2016, involved in the two-week teacher training programme, observed various training sessions and had several interactions with those trainee teachers, and I learned that rural government schools were gradually shifting from Nepali to English medium. Mahendra Kathet, as mentioned above, was one of the trainers who strongly focuses on the importance of English as a medium of instruction for some reasons:

Careers that involve lots of travel and international exposures such as the airline, tourism, film industries, etc. use the English as their official language and many employers in these sectors demand a certain level of proficiency in English. The proficiency in English broadens social networking and increases our chances of getting a good job in foreign countries (2015).

Kathet's account seems to be logical from the global perspective need for exploring opportunities, but his narrative, however, raises an issue that whether he wants schools to teach the English language only, regardless of teaching several other subjects such as Social Studies, Science, Maths, Nepali and other optional subjects which are in the Nepali language. His account provides a space for several criticisms as such whether he expects all the schools in Nepal to be English language learning centres similar to those in city corners which teach several international languages including the English, or he wants all new generation Nepali people to be English monolingual ignoring native languages and without learning other life skills. However, Ishwor Kadel, a teacher trainer, in his narrative article talks about the English language as a need of students and parents and the challenge of implementing English as a medium of instruction in schools where most of the teachers themselves cannot communicate in English and do not have English language proficiency that they require: 
The developing craze for the English language among students and parents brought most of the students from community schools to private boarding schools. The number of students in public schools has been decreasing gradually in Nepal. The students, though they learn the English language from primary level cannot communicate in English and they do not easily comprehend the texts they use. The students and most of the primary teachers do not have good command over the English language. But many public schools have started introducing the English language as a medium of instruction. This has made EMI training to public school teachers a must. After the completion of EMI training, the trained teachers can use English as a medium of instruction, plan their own lessons, prepare teaching materials, train other teachers and become more creative (Kadel, 2015 August 9).

Kadel's narrative as such the account of Kathetaligns with the argument of Giri (2011) that the majority of people in Nepal have a neo-colonial belief: the English language ensures an access to a wide range of opportunities and better future of the growing generation of youths. Kadel's narrative indicates that government schools are unable to fulfil parents' expectation that their children would learn the English language from their schools, and this has provided private schools with an opportunity to increase their educational business. His account also shows that the reason behind shifting government schools from Nepali to English medium is to hold their students in the government schools from going out to private English medium schools. This has raised concerns that perhaps government schools have been unable to ensure the quality of education and convince community people about their educational activities. However, Kadel's account suggests that teachers, teacher trainers, educators, and policymakers need to understand the contexts, particularly rural areas of Nepal where there are several indigenous languages including Nepali, a dominant national language and the English is a foreign language. His contradictory statements, as he says that both teachers and students have a lack of English language skills, and he claims that a short-term training in how to use the English as medium of instruction in Nepali government schools' classrooms makes teachers able to use the English as classroom instructional language, raise questions against the teacher training system, trainers' qualification and national education goal. This suggests that he among many other teacher trainers in the country who is protecting his job of training, regardless of being realistic in multilingual contexts of Nepal, where the English is one of the foreign languages taught in schools, needs to learn about social, cultural and linguistic diversity of Nepal and include these properties in educational activities.

\section{The expectation of changing educational quality in schools}

The ongoing debate on how the quality of education can be improved has been a political agenda in Nepal, particularly since the re-establishment of multi-party democracy in 1991. The democratic government's flexible education policy provided individuals with an opportunity to open private schools, which was a kind of strategy to develop a competition between government schools and private schools and to improve the educational quality of government schools. However, the proliferation of private schools gradually created a gap between government and private schools. Instead of developing academic collaboration, private 
schools, which own sole authority to manage themselves, increasingly developed an environment particularly in cities where they were able to gain people's motivation and trust with their identity of the English language business and government schools lost the public trust. Although education is free in government schools and people have to pay expensive fees in private schools, people who can afford the expensive education prefer to enrol their children in private schools and otherwise, they send their children to government schools. Regardless of talking about teachers' involvement in various political parties, crossroad conversations about government schools and education are mostly oriented towards a political alliance of government school teachers and their lack of responsibility at their workplace. In recent years, several hundreds of government schools, particularly primary ones, have been either merged into one or shut down forever due to lack of students. These are probably some of the indicators of rising issues regarding the quality of education in government schools and future researches may explore evidence about the issues.

Several teachers in their narratives have emphasised that the use of English as a classroom language will improve the quality of education, and some teachers resent the schools' approach to make the English as a medium of instruction in Nepali schools. However, many teachers' narratives indicate that the quality of education is usually measured depending on the results high schools achieve in Secondary Education Examination (SEE) board in Class Ten (Year Ten) and that children's capability of using the English language is a major indicator of the quality of education. The excerpt depicted from Kathet's narrative article can be a good example to understand the perceived value of the English language in Nepal:
High school graduates from community schools have failed to develop their proficiency in English in school. Whereas, the proficiency level of graduates from private schools is better than of community schools. When analysed the gaps, the only tangible difference between private and community schools is the medium of instruction. Private schools have been using English as a medium of instruction (EMI) while Nepali is the medium of instruction in community schools (2015 August 9).

Although Kathet does not explain why students in community schools are unable to develop English language proficiency, there might be many factors such as lack of teachers' English proficiency, learning environment in schools and English as a foreign language in multilingual Nepali communities. However, his narrative reflects that imposing the English language in students will improve the quality of education in government schools and that the students from government schools will meet the level of private schools. His reason for making the English as an instructional language in Nepali schools seems to be inconsistent with psychological principles of learning, and this provokes questions against the qualification of teachers and educators. There is no empirical evidence found to support his idea that the English as a medium of instruction assures the improvement of the quality of education. Instead, the decision that many community schools have made to shift from Nepali to English medium is absurd and it is against the right to education in mother tongue in school as stated in Nepal's Constitution, 2015.

Ashok Khati, who has been a teacher for about twenty years as well as a teacher trainer for several years, doubts whether or not the initiatives of those schools which 
have adopted English as a medium of instruction would improve the quality of education:

Public schools are adopting EMI so that they can acquire more quotas for new teachers from the government. More strikingly, teachers take for granted that teaching in English helps students find jobs and participate in the global community. They also believe that students' progress in the English language contributes to more access to information and knowledge. Both the teachers and guardians mean EMI leads to quality education. Sadly, there are not any support and teaching resources that can help the teachers to effectively conduct their classes in English medium. Very few teachers find EMI classroom pleasant and exciting in several contentrelated subjects. Most teachers who have been teaching in Nepali medium of instruction for decades in the past find EMI very challenging. They feel their schools adopting EMI has posed a burden on their profession. This tendency might hinder teaching-learning activities (Khati, 2015, August 9).

Khati argues that the schools, which have adopted English as a medium of instruction, have made the decision without any directive and plan of the government, but with their own interest and individual strategy to bring changes in the schools. His narrative, for instance, the above excerpt, reflects his anxiety that the schools' hasty decision to shift from Nepali to English medium may deteriorate teaching and learning environment in schools and bring frustration in teachers.

Several studies (Cook, 2001; Cummins, 2001; Hovens, 2002; Ndamba, 2008) have reported that learning takes place when the learners understand what they need to learn, and bilingual children learn better in their mother tongue. However, many government schools in Nepal, who have shifted from Nepali to English medium and many others whichhave thought tofollow them, have neglected the reality of the Nepali contexts where children have their own mother tongue as well as national language and they learn English in school. The idea of imposing the English as an instructional language for children in Nepali schools is irrational, and it is, as Giri (2011)alleged neo-colonial ideology.

Kathet's idea of improving the quality of education by shifting all Nepali schools from Nepali to English medium signposts the future threat of losing native identities such as social, cultural and linguistic diversities and also creates a confusion between language and education. His belief reminded me Biggs' (1990) findings in Hong Kong schools that the imposition of English as a medium of instruction in the classrooms in the late 1980s led students to memorise contents instead of learning what they needed to learn from daily classes. In the context of Nepal, the pressure of English as a medium of instruction on students in Nepali schools not only betrays students from learning but makes them robotic because Englishis a new language they learn in schools but is not commonly used in their daily life. In government schools where almost all teachers cannot communicate in English (Kadel, 2015 August 9), the holistic approach of shifting schools from Nepali to English medium will pressurise several teachers to leave their teaching profession and search alternative jobs. This will gradually break down the education system, produce unproductive graduates and require reformation of the education system. 


\section{Policy on national and foreign languages}

Many teachers' narratives reflect tensions about language policy of Nepal, linguistic hegemony and language for education. Particularly the language for education and foreign language in school education seem to be a major concern in Nepal's school education system. Nepal, having 123 languages among 125 ethnic communities as discussed earlier, has a complicated socio-political stress to include social, cultural and linguistic diversity in national education policy and protect these properties. Nepal's Constitution, 2015 (Constitutional Assembly Secretariate, 2015) states that the implementation of the constitution will address the issue of inclusion of ethnic entities, which have been made political agenda by several political parties for several decades but have never been addressed. The constitution states that members of the public have a right to get the formaleducation in their mother tongue. It is expected that the constitution will resolve the problems regarding minority languages, which have been seeking a status of official language and space in education. However, it is too early to say how the government and schools operate their educational activities in multilingual communities and what strategies they are going to develop to conduct bilingual or multilingual classrooms in this existing monolingual education system. In one way, the new policy provides children with an opportunity for learning in their mother tongue and in another way, this will protect several minority languages of the country. However, teachers' narrativesindicate that fragile language policy and the place of the English language in school education are other major problems. For example, as discussed above, several government schools have shifted from Nepali to English medium in the recent years without any official plan, policy, and directive of government, which shows the weakness of Nepal's national education policy, the fragility of language policy and meager governance. Khati (2015 August 9) argues that, although several schools have chosen EMI as an instrument to improve the quality of education, there is no empirical evidence found to support their ideology. He suggests that schools need to be able to differentiate between teaching the English language and teaching in English before planning to adopt EMI in Nepali schools.

Schools do not have any strategic plan to teach students through EMI. Teaching through second or foreign language is an entirely different issue from teaching academic subjects through the first language (Khati, 2015 August 9).

Khati'sargument aligns with the findings of Phyak (2011) that neither the schools have a particular plan for shifting from Nepali to English medium, nor the government has a standard language policy and an ability to make commitments. Hestresses that the idea of making English as an instructional language in Nepali government schools will be a barrier for children to learn new things and it will decline their creativity of learning instead of supporting them in their learning activities. He argues that the schools' idea of making the English as a medium of instruction is only a key to sell them in the market, which other private schools have been doing for three decades, in the name of improving education quality. Giri (2011) states that the language policy of Nepal is always conjugated with the English language, and therefore, the English language has got an undeniable status in Nepal's educational development. He argues that the invisible politics of language within the country, which is visible in ambiguous terminologies: "language of the nation" for Nepali and "national languages" for other ethnic/ minority languages stated in the 
constitution, has illustrated a fragility of language policy. He further argues that dynamic process of language policy development is never considered as a multidisciplinary, and suggests that the issues regarding languages should be openly discussed and public voice should be valued in the process of developing language policy.

However, Gaulee (2012 January 1) argues that the foreign influence over Nepal's social, educational and economic policies has promoted the English language in Nepal and dominated local languages:

There are arguments that the spread of the English language all over the world did not happen automatically. This has been systematically proliferated by agencies and this proliferation is still on. Languages are often imposed by powerful countries to foster their own languages.

His argument is, at some level, consistent with Mustapha (2014) that the dominant role of politically and economically powerful countries influences the educational policies including social, political and economic aspects of developing counties. Phillipson (1997) and Modiano (2001) stress that internationalised English language learning based on culture-specific perspective norms is an imperialistic approach, which exploits one society by another. Phillipson argues that the linguistic hegemony, although it consciously or unconsciously reflects dominant attitudes, does not indicate predispositions and there is always a room for people to choose their language, but he stresses that there may be linguistic hegemony when one language is associated with donor country. He further stresses that the linguistic hegemonic belief creates a conflict in educational language policymaking, for example, education through the medium of English or English language education, which is an issue in Nepal. Many teachers (Khati, 2015 August 9; Phyak, 2015 August 9; Sah, 2015 August 9; Sharma, 2015 August 9; Sharma, 2017 June 11) through their narratives suggest that the idea of making the English language as a medium of instruction in Nepali schools, where the English language is taught as a subject like Mathematics, Science and Nepali, is impractical. Instead, they emphasise that the bilingual education system is required in the multilingual context of Nepal and the government needs to develop and implement standard language policy to solve language-related problems in the country.

\section{The bilingual approach to classroom teaching}

Most of the communities in Nepal are bilingual but several languages exist widely scattered. It is probably the first challenge to identify who speaks what language in particular communities and then to develop a language plan and materials in the language. In absence of researches in those several languages and lack of standard statistical data, the official language policy and political decisions may not work effectively and practically. Phyak (2011) stresses that, although the Curriculum Development Centre has developed curriculum and textbooks in 18 different indigenous languages, there are other challenges such as how to develop teachers' professionalism in a particular language and convince parents to teach children in their mother tongue. However, he emphasises that it is necessary to implement the constitutional commitment of teaching in mother tongue to foster children's basic communication skills and develop their self-esteem. Children think in their mother tongue and can learn social and cultural values instinctively in their first language (Rana, 2017, June 11). Some 
teachers' (Phyak, 2015 August 9; Pyhak, 2011 March 11; Sah, 2015 August 9; Sharma, 2015 August 9; Yadav, 2013 December 1) narratives indicate that multilingual pedagogy can be an appropriate approach in Nepali schools as the majority of children have their own mother tongue. Yadav (2013 December 1) exemplifies that literacy programmes conducted by NGOs in the Terai region, particularly in Rajbansi and Tharu communities, in their indigenous languages: Rajbansi and Tharu, encouraged the communities to educate their children in their mother tongue and motivated children to learn in the classroom.

Agnihotri (2013) in his narrative argues that observing children's mother tongue as an obstacle to learn other languages and different subjects in the classroom is a predisposition which interferes with the natural process of children's learning. He stresses that bilingualism or multilingualism in education in Nepal is not a problem but there is always a political power to continue a monolingual education system. Giri (2011) argues that the invisible politics for decades has been playing a drama on the linguistic diversity of Nepal to strengthen one language policy in the country and that the government has never tried to change monolingual education system to bilingual education system. However, the English language has been emphasised in education as discussed above. Leaving several indigenous languages behind, the English language has got a second priority after the Nepali language in education, and this has created a tension among various ethnic communities in the country.

Sharma (2016 January 1) stresses that without trying to understand the actual local challenges of education and diversity of languages in Nepal, stakeholders such as schools, parents, teachers, and educators are adopting English-only medium of instruction, an idea which they think it will magically improve the quality of education. He argues that instead of improving education in government schools with only English idea by replacing Nepali and local languages, the situation will be worse because the teachers cannot speak well and students have limited opportunity to develop their English language competence. Many other teachers also criticise the only English idea that few students may at some level master nuance of English after being forced to use it for a decade or more but it is unlikely to be successful in the context of Nepal and many schools have miserably failed to achieve their expected goals due to insufficient resources. Sharma (ibid) suggests the multilingual approach in Nepali schools which allows teachers and students to learn diverse ideas in more than one language, to improve their learning and to increase opportunities in their life. Yadav (2017 June 11), an experienced teacher of English language, suggests that language policy, although it is a serious and difficult task to develop, should be inclusive and has to protect languages as an indicator of social identity. He emphasises that the bilingual education system is perhaps an appropriate way to solve many problems related to the diversity of languages.

\section{Conclusion}

The discussions above show that there is a lack of inclusive multilingual language policy in Nepal to address the diversity of languages as an indicator of the social and national identity of several indigenous communities. Although the vague statements of recently promulgated Nepal's Constitution, 2015 assures the right to education in mother tongue in school, there are a number of challenges, such as teacher development in a particular language, development of strategic plans for various languages and implementation in education, to realise the norm of the right provided for the citizens of Nepal. 
This article demonstrates that the absence of clear-cut national language policy in Nepal resulted in unsystematic changes in school education as such many government schools shifted from Nepali to English medium and some others are in the process. The decision many government schools have made to adopt the English as a medium of instruction is neither conscious effort nor a wise idea in the multilingual context of Nepal where children learn the English language as one of many subjects in the classroom but do not use it in their daily life. Instead of improving the quality of education that many government schools have expected by shifting from Nepali to English medium, the imposition of English as an instructional language on children will betray them from learning and gradually make education worse. The English language interest of schools, parents and educators in Nepal is likely to promote English language hegemony over several local languages including Nepali, the national language and endanger social, cultural and particularly linguistic diversity of Nepal. In the context of Nepal, it is wise to choose bilingual education system which provides teachers and learners with opportunities for learning diverse ideas in more than one language, for improving their learning and for increasing job opportunities in their life.

\section{References}

Agnihotri, R. K. (2013). What should one do in a language classroom? ELTChoutari. Retrieved from https:// neltachoutari.wordpress.com/2013/ $07 / 01 /$ what-should-one-do-in-alanguage-classroom/

Alexander, N. (2009). The impact of the hegemony of English on access to and quality of education with special reference to South Africa. Language and poverty, 141, 53.
Biggs, J. B. (1990). Effects of language medium of instruction on approaches to learning. Educational Research Journal, 5, 18-28.

Central Bureau of Statistics. (2011; published 2012 November). National Population and Housing Census 2011 (National Report). Kathmandu, Nepal: National Planning Commission Secretariat, Central Bureau of Statistics, Government of Nepal.

Constitutional Assembly Secretariate. (2015). Nepal's Constitution, 2015 (2072 BS). Constitutional Assembly Secretariate, Singhadurbar, Kathmandu.

Cook, V. (2001). Using the first language in the classroom. Canadian Modern Language Review, 57(3), 399-423.

Cummins, J. (2001). Bilingual children's mother tongue: Why is it important for education. Sprogforum, 7(19), 15-20. Retrieved from https:// doc.uments.com/s-bilingualchildrens-mother-tongue-why-is-itimportant-for-education.pdf

Gaulee, U. (2012 January 1). Millennium development goals, education for all and the issue of dominant language. ELTChoutari. Retrieved from http:// eltchoutari.com / $2012 / 01 /$ millennium-development-goalseducation-for-all-and-the-issue-ofdominant-language/

Giri, R. A. (2009). The politics of 'unplanning' of languages in Nepal. Journal of NELTA, 14(1), 32-44.

Giri, R. A. (2011). Languages and language politics: How invisible language politics produces visible results in Nepal. Language Problems and Language Planning, 35(3), 197-221. doi: 10.1075/lplp.35.3.01gir

Guo, Y., \& Beckett, G. H. (2007). The hegemony of english as a global 
language: Reclaiming local knowledge and culture in China. Convergence, 40(1/2), 117-132.

Hovens, M. (2002). Bilingual education in West Africa: Does it work? International Journal of Bilingual Education and Bilingualism, 5(5), 249266. doi: 10.1080/13670050208667760

Jenkins, R. (2004). Social identity. London, USA \& Canada: Routledge.

Kadel, I. (2015 August 9). Project NIITE: Developing better teachers for implementing EMI. ELTChoutari. Retrieved from http:// eltchoutari.com/2015/08/projectniite-developing-better-teachers-forimplementing-emi/

Karn, S. K. (2009 October 1). English as a bonus. ELTChoutari. Retrieved from http:/ / eltchoutari.com/2009/10/ english-as-a-bonus /

Kathet, M. (2015 August 9). EMI in community schools: A case from Mt. Everest. ELTChoutari. Retrieved from http:/ / eltchoutari.com/2015/08/ emi-in-community-schools-a-casefrom-mt-everest-region/

Khati, A. R. (2015 August 9). EMI in Nepal: A Passport to a competitive world or a commodity to sell? A case study. ELTChoutari. Retrieved from http:// eltchoutari.com/2015/08/emi-innepal-a-passport-to-a-competitiveworld-or-a-commodity-to-sell-a-casestudy/

Krauss, M. (1992). The world's languages in crisis. Language, 68(1), 4-10.

Lane, J. (2017 May 10). The war on local languages - how linguistic hegemony threatens education in the developing world. Babbel Magazine. Retrieved from https://www.babbel.com/en/ magazine / the-war-on-locallanguages-how-linguistic-hegemony- threatens-education-in-thedeveloping-world/

Luhtanen, R., \& Crocker, J. (1992). A collective self-esteem scale: SelfEvaluation of one's social identity. Personality and Social Psychology Bulletin, 18(3), 302-318. doi: 10.1177/ 0146167292183006

Macedo, D., Dendrinos, B., \& Gounari, P. (2005). The hegemony of English. Teaching Issues, 39(1), 125.

McCrone, D., \& Bechhofer, F. (2008). National identity and social inclusion. Ethnic and Racial Studies, 31(7), 12451266. doi: 10.1080/ 01419870701704677

Modiano, M. (2001). Linguistic imperialism, cultural integrity, and EIL. ELT Journal, 55(4), 339-347. doi: 10.1093/elt/ 55.4 .339

Mustapha, A. S. (2014). Linguistic hegemony of the English language in Nigeria. Íkala, Revista de Lenguaje y Cultura, 19(1), 57-71.

Ndamba, G. T. (2008). Mother tongue usage in learning: An examination of language preferences in Zimbabwe. Journal of Pan African Studies, 2(4).

Phillipson, R. (1996). Linguistic imperialism: African perspectives. ELT Journal, 50(2), 160-167.

Phillipson, R. (1997). Realities and myths of linguistic imperialism. Journal of Multilingual and Multicultural Development, 18(3), 238-248. doi: $10.1080 / 01434639708666317$

Phyak, P. (2015 August 9). Reimagining education from a multilingual perspective: Policies/practices, realities and looking forward. ELTChoutari. Retrieved from http:// eltchoutari.com/2015/08/ rei m a gining-e mi - f rom - a multilingual-perspective- 
policiespractices-realities-andlooking-forward/

Phyak, P. B. (2011). Beyond the façade of language planning for Nepalese primary education: Monolingual hangover, elitism and displacement of local languages? Current Issues in Language Planning, 12(2), 265-287. doi: $10.1080 / 14664208.2011 .584203$

Pyhak, P. (2011 March 11). Teaching English in multicultural contexts: More challenges and even more opportunities. ELTChoutari. Retrieved from http:/ / eltchoutari.com/2011/ 03/teaching-english-in-multiculturalcontexts-more-challenges-and-evenmore-opportunities /

Rana, K. (2017 June 11). So what, if not mother tongue? ELTChoutari. Retrieved from http:// eltchoutari.com/2017/06/so-what-ifnot-mother-tongue/

Rana, K. (2018). ICT in rural primary schools in Nepal: context and teachers' experiences. (Thesis). University of Canterbury, New Zealand. Retrieved from https://ir.canterbury.ac.nz/ handle/10092/457

Sah, P. K. (2015 August 9). English medium instruction (EMI) in Nepalese education:Potential or problem? ELTChoutari. Retrieved from http:// eltchoutari.com/2015/08/englishmedium-instruction-emi-in-nepaleseeducationpotential-or-problem/

Shannon, S. M. (1995). The hegemony of English: A case study of one bilingual classroom as a site of resistance. Linguistics and education, 7(3), 175-200.

Sharma, B. K. (2015 August 9). Why English-only ideology and practice. ELTChoutari.

Sharma, S. (2016 January 1). Beauty and power of multilingualism. eltchoutari. retrieved from http:// eltchoutari.com/2016/01/beautyand-power-of-multilingualism/

Sharma, S. (2017 June 11). Beyond beating dead horses. ELTChoutari. Retrieved from http://eltchoutari.com/2017/ 06/beyond-beating-dead-horses/

Tupas, T. R. F. (2001). Global politics and the Englishes of the world. In A. E. Ife \& J. Cotterill (Eds.), Language across boundaries (pp. 81-98). London: Continuum.

Weinberg, M. (2013). Revisiting history in language policy: The case of medium of instruction in Nepal. Working Papers in Educational Linguistics (WPEL), 28(1), 6.

Yadav, G. K. (2017 June 11). Language practices and food for thought for language policy makers. ELTChoutari. Retrieved from http:// eltchoutari.com/2017/06/languagepractices-and-food-for-thought-forlanguage-policy-makers /

Yadav, P. K. (2013 December 1). Towards multilingual education in Nepal. ELTChoutari. Retrieved from http:/ / eltchoutari.com/2013/12/towardsmultilingual-education-in-nepal/

\section{Contributor}

Karna Rana has recently completed his PhD from the University of Canterbury, New Zealand in the field of Nepal's rural primary teachers' ICT practice in the classroom. After his Masters in English Education (MEd) from Nepal, he has done his second Masters in Education (MA) from the University of Bedfordshire, England. He has taught English language and Linguistics in Nepal for about 20 years. 